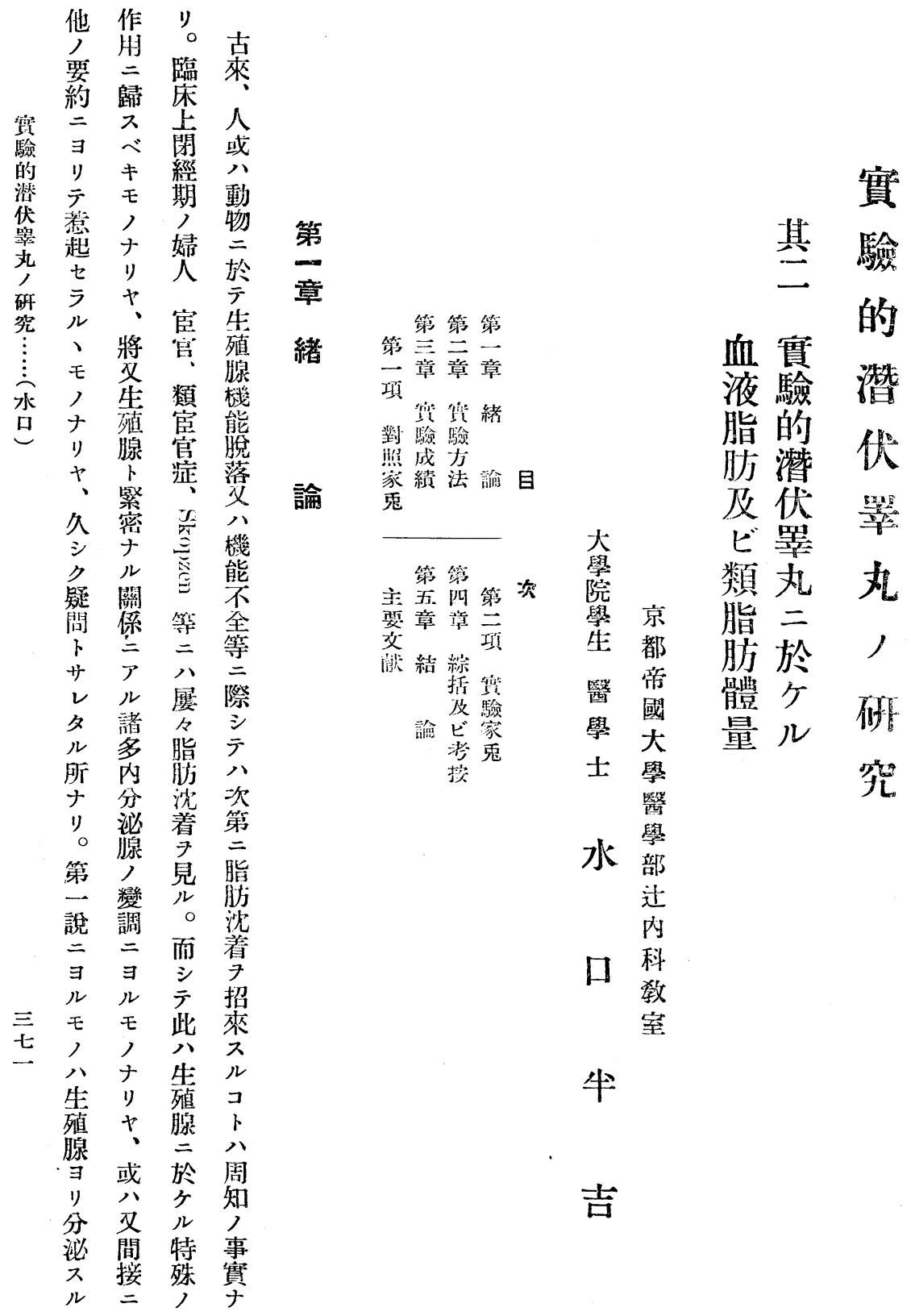


“ ル 殖

氏, 八下

法 報 $\boldsymbol{\nearrow}$

尹 告 ビテ

用多心

七 $ミ$

先所, 躴

当ナ1内

試 $v$ 外

瞼 バ

前此 ヨ 雄

子少變成

充 性 熟

卜 分 7 家

王, 起香

可湆

) 7 个

剆 拂 先 賽

定 進歌

征前

行、業少

略全靕 多

品見壬

一, , 党

定總所 日

七脂及間

ル肪癿舅

確酸肪謇

$x \geq$ 謝 中

後光毠市

潛不同

桨テビ方

辡り多食

杂手、令

術と1聶

于尼取

行 $=$ 三

七 $ン$ シ

量り

手是影 タ

術測響 リ

方筀七
就

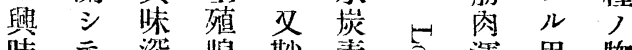

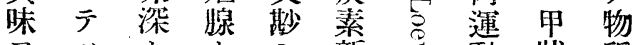

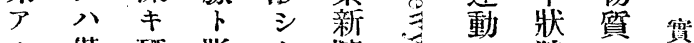

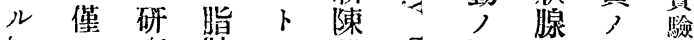

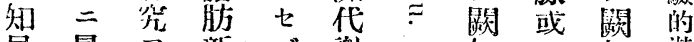

見最了新 ズ 謝如公如潜

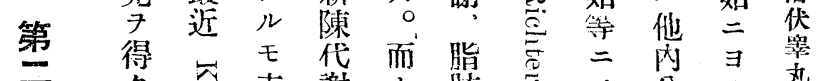

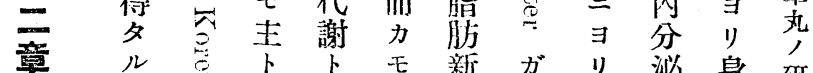

ル

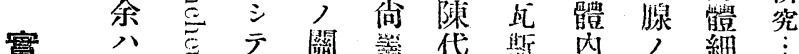

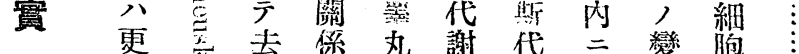

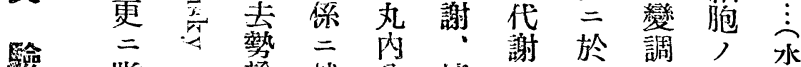

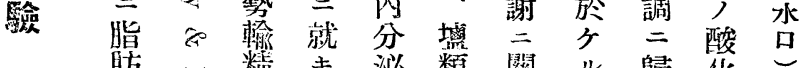

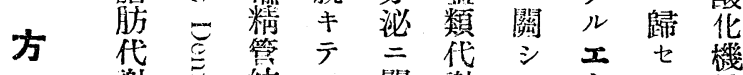

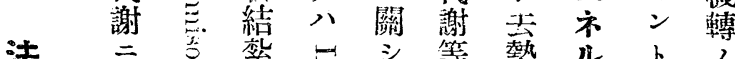

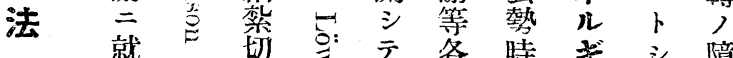

寺除至分方及! 第碍

報 腹其面 ビ消志

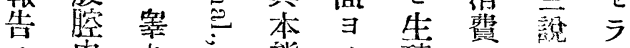

ス内规態り殖了二ル

ル脂物气等幾脽减寻、

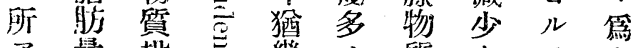

ア量投き幾, 留七モな

ラ 測與小多菜投

ン定人林人嚓與儿八卜

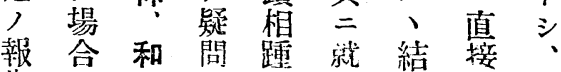

告了田 71 年果第

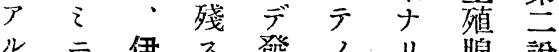

, 三伊

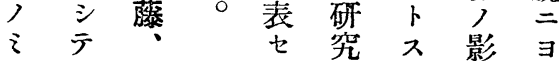

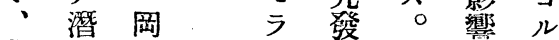

茲森畞表生

二鼠、它殖ア, 三

於丸奧從儿腺ラ八士

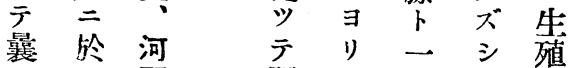

二分野䦜以般示腺

組儿、明來新寧学

織脂大 七窒陳品密

學肪村 5 素代精接

的新、彩謝神宁

變陳久 夕陳气的儿

花代保等代就㮅關 
第一表 對照家鬼（百竜中二於ケル瓦）

\begin{tabular}{|c|c|c|c|c|c|c|c|c|c|c|}
\hline \begin{tabular}{|l|} 
家鬼 \\
番號
\end{tabular} & & 前 & 5 日 & 10日 & 20 日 & 30 日 & 40 日 & 50 日 & $60 日$ & 75 日 \\
\hline I & 總脂放酸 & 0.333 & 0.336 & 0.329 & 0.342 & 0.332 & 0.336 & 0.338 & $0.335^{\prime}$ & 0.336 \\
\hline 對 & コレステリン & 0.117 & 0.121 & 0.122 & 0.122 & 0.126 & 0.111 & 0.115 & $0.11:$ & 0.121 \\
\hline & レキチン & 0.185 & 0.180 & 0.182 & 0.182 & 0.195 & 0.191 & 0.182 & 0.189 & 0.187 \\
\hline 照 & 能霯 重 & 1980 & 1980 & 2000 & 2050 & 1990 & 2030 & 2070 & $20 \pi 0$ & 2070 \\
\hline II & 總 脂 肪 酸 & 0.292 & 0.295 & 0.302 & 0.293 & 0.292 & 0.289 & 0.064 & 0.207 & 0.362 \\
\hline 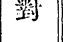 & 3レステリン & 0.139 & 0.137 & 0.140 & 0.138 & 0.144 & 0.137 & 0.142 & 0.144 & 0.147 \\
\hline & レチチン & 0.208 & 0.204 & 0.209 & 0.210 & 0.200 & 0.219 & 0.217 & 0.212 & 0.214 \\
\hline 照 & 體 而 & 1920 & 1920 & 1970 & 1990 & 2020 & 2010 & 2020 & 2080 & 2030 \\
\hline III & 總脂 肪漼 & 0.245 & 0.252 & 0.247 & 0.252 & 0.241 & 0.247 & 0.251 & $0.24 \%$ & 0.242 \\
\hline 手 & コレステリン & 0.100 & 0.105 & 0.103 & 0.107 & 0.102 & 0.108 & $0.110^{\prime}$ & $0.10 \%$ & 0.105 \\
\hline 對 & Vチチン & 0.191 & 0.193 & 0.192 & 0.191 & 0.196 & 0.194 & 0.196 & 0.191 & 0.194 \\
\hline 照 & 體䨐 & 2050 & 2010 & 2070 & 2030 & 2050 & 2120 & 2130 & $2 i(6)$ & 2100 \\
\hline IV & 總 脂 肪 酸 & 0.303 & 0.307 & 0.312 & 0.301 & 0.317 & 0.312 & 0.319 । & 0.512 & 9.808 \\
\hline & コレステリン & 0.117 & 0.117 & 0.120 & 0.122 & 0.119 & 0.124 & 0.127 & 0.119 & 0.115 \\
\hline 龇 & レキチン & 0.182 & 0.187 & 0.181 & 0.185 & 0.191 & 0.194 & 0.181 & 0.180 & 0.190 \\
\hline 照 & 娟 重 & 2070 & 2090 & 2100 & 2120 & 2120 & 2100 & 2120 & 2150 & 2170 \\
\hline 本 & 總脂 肪 浐 & 0.293 & $0.29 \overline{0}$ & 0.297 & 0.297 & 0.294 & 0.295 & 0.300 & 0.298 & 0.297 \\
\hline & コレステリン & 0.119 & 0.120 & 0.122 & 0.122 & 0.123 & 0.120 & 0.124 & 0.122 & 0.122 \\
\hline 均 & レチチン & 0.192 & 0.191 & 0.191 & 0.192 & 0.195 & 0.199 & 0.194 & 0.143 & 0.196 \\
\hline
\end{tabular}

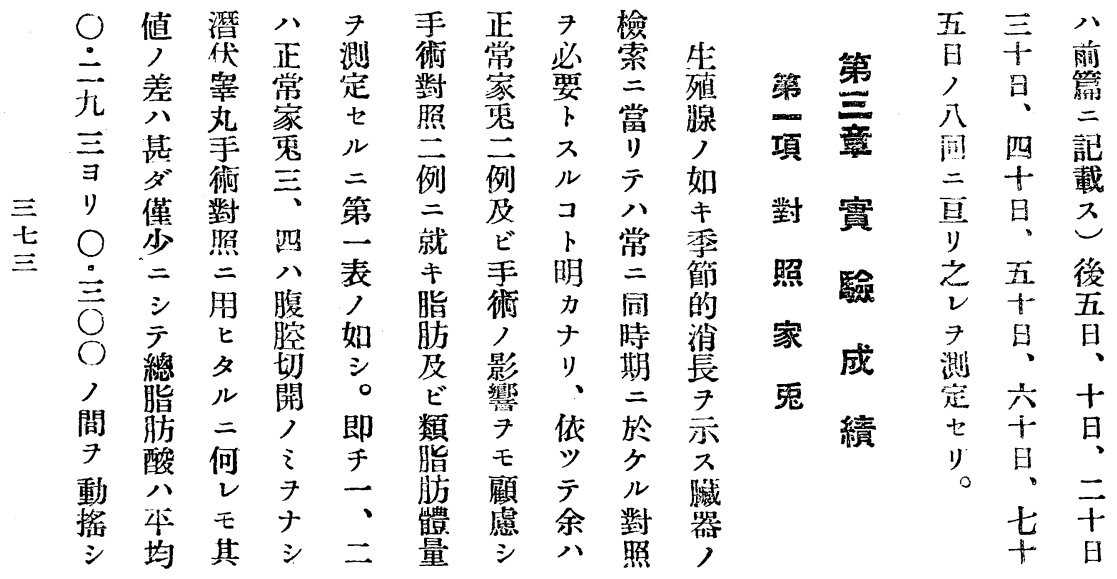


第二表 淐伙繁扎家鬼（百竜中二於ヶル瓦）

\begin{tabular}{|c|c|c|c|c|c|c|c|c|c|c|}
\hline 家鬼 & & 前 & 5 日 & 10 म & 20 日 & 30 日 & 40 日 & 50 日 & 60 日 & 75日 \\
\hline & 總脂 肪酸 & 0.270 & 0.271 & 0.260 & 0.258 & 0.268 & 0.282 & 0.279 & 0.294 & 0.311 \\
\hline I & コレステリン & 0.122 & 0.109 & 0.115 & 0.122 & 0.127 & 0.137 & 0.145 & 0.147 & 0.142 \\
\hline & レ‡チン & 0.183 & 0.180 & 0.180 & 0.188 & 0.199 & 0.200 & 0.197 & 0.209 & 0.205 \\
\hline & 骴豊 & 1950 & 2000 & 1970 & 1900 & 1950 & 2030 & 2070 & 2030 & 2050 \\
\hline & 䊽恖脂勋 酸 & 0.226 & 0.224 & 0.225 & 0.279 & 0.341 & 0.347 & 0.344 & 0.351 & 0.348 \\
\hline II & コンステリン & 0.110 & 0.109 & 0.110 & 0.115 & 0.114 & 0.135 & 0.167 & 0.175 & 0.177 \\
\hline & とチチン & 0.188 & 0.183 & 0.187 & 0.180 & 0.192 & 0.195 & 0.230 & 0.221 & 0.230 \\
\hline & 變: & 2120 & 2140 & 2150 & 2150 & 2170 & 2330 & 2150 & 2200 & 2200 \\
\hline & 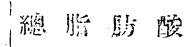 & 0.317 & 0.301 & 0.303 & 0.341 & 0.347 & 0.356 & 0.366 & 0.369 & 0.357 \\
\hline III & コレステリン & 0.126 & 0.122 & 0.121 & 0.147 & 0.157 & 0.150 & 0.159 & 0.141 & 0.147 \\
\hline & レ干干ン & $0.20 \tilde{\jmath}$ & 0.200 & 0.207 & 0.229 & 0.235 & 0.237 & 0.240 & 0.240 & 0.235 \\
\hline & 能致重 & 2050 & 2100 & 2050 & 2150 & 2100 & 2170 & 2130 & 2170 & 2180 \\
\hline & 總脂 & 0.262 & 0.255 & 0.260 & 0.267 & 0.302 & 0.833 & 0.319 & 0.354 & 0.355 \\
\hline 15 & コレステリン & 0.143 & 0.140 & 0.135 & 0.147 & 0.153 & 0.16 .5 & 0.167 & 0.171 & 0.169 \\
\hline & ᄂ $千 F$ & 0.207 & 0.200 & 0.203 & 0.219 & 0.238 & 0.244 & 0.250 & 0.248 & 0.241 \\
\hline & 鼎重 & 1900 & 1870 & 1900 & 1970 & 2000 & 1950 & 2070 & 2050 & 2090 \\
\hline & 總脂 应 酸 & 0.271 & 0.260 & $0.252^{\prime}$ & 0.271 & 0.287 & 0.295 & 0.307 & 0.315 & 0.347 \\
\hline $\mathrm{r}$ & コレステリン & 0.134 & 0.135 & 0.138 & 0.145 & 0.165 & 0.171 & 0.176 & 0.169 & 0.177 \\
\hline & உチチン & 0.193 & 0.180 & 0.182 & 0.195 & 0.201 & 0.207 & 0.217 & 0.209 & 0.211 \\
\hline & 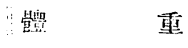 & 1890 & 1870 & 2070 & 2050 & 2030 & 2070 & 2070 & 2100 & 2070 \\
\hline 平 & 總 照 酳 酸 & 0.269 & 0.262 & 0.260 & 0.283 & 0.309 & 0.313 & 0.323 & 0.336 & 0.343 \\
\hline & コレステりン & 0.123 & 0.123 & 0.124 & 0.135 & 0.143 & 0.151 & 0.163 & 0.160 & 0.162 \\
\hline 均 & レテチン & 0.195 & 0.188 & 0.191 & 0.202 & 0.214 & 0.216 & 0.217 & 0.225 & 0.224 \\
\hline & 第 & - & & & ン & 自 & 重 & ᄀ & 八 & $\beth$ \\
\hline & ビ & 定 & 㤐啐 & & 力 & 然 & $=$ & 間 & & - \\
\hline & 類 & $J$ & 丸 & 㿦 & 0 & 塭 & 八 & 7 & & $\pi$ \\
\hline 女 & 脂 & 經 & 7 & $=$ & & 加 & - & 動 & & $\bar{\gamma}$ \\
\hline 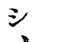 & 肪 & 過 & 腹 & 項 & & $r$ & 定 & 遙 & 九 & ) \\
\hline & 體 & $=$ & 腔 & & & 考 & ) & $\pi$ & 一 & 四 \\
\hline & 垔 & 從 & 內 & 窗 & & $人$ & 縔策 & ル & $\exists$ & ノ \\
\hline & 稍 & t & $=$ & & & ル & 化 & $=$ & リ & 間 \\
\hline & 测 & テ & 潛 & & & 八 & 7 & 過 & $\Omega$ & 7 \\
\hline & 定 & 血 & 伏 & 家 & & 至 & 認 & ギ & & L \\
\hline & 重 & 液 & 七 & & & 當 & $x$ & ズ & & $F$ \\
\hline & ル & 脂 & シ & 5 & & ナ & 䧼 & 0 & 九 & f \\
\hline & - & 肪 & $x$ & & & ラ & キ & 䪆 & 宍 & $v$ \\
\hline
\end{tabular}


筫先事今 $\begin{aligned} & \text { 徒 } \\ & \text { 日家 }\end{aligned}$

投累二生。於公

與瓦 殖家

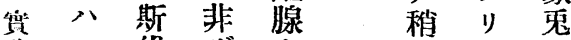

驗コ代ザト な テ タ

的) 謝儿脂减八物

潜 低 こ 肪 少 - 七

罣下 關 シ 新定實

寺七 ス。陳傾了驗

少代向範的

研瓦无謝

究斯, 年示内潛

$\vdots$ 代 7 的, 伏

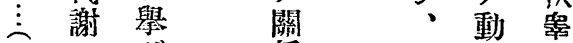

水 $ケ$ 年 二採 丸

口卡

日 示腹

シ

ム 只 ズ

ル $\approx$

ᄀ $\div$

○當

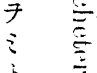

i

x 八 新

而 旵

$\vdots$ 二

方於

己 テ

几去

八勢

至 二

勢 ヨ

二 リ

$\exists \quad \bar{\gamma}$

$=$ リ

七酸 瓦

五.
系代

費 解

量 7

减 低

退 下

來 七

シ $x$

辢 锌

丸 犯
资賽 驗

第家 リ

二 恴 血

增 二 菠

量 $ア$ 脂

シリ肪

六テ度

十八ビ

日 總 類

前脂 脂

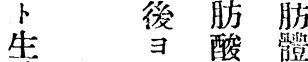

殖少量

腺略コテ

卜 \& 2 测

最最定

關 高 テ シ

係卜前

二 ナン 述

就

キ

₹

七手對

文儿照

値 共家

顧 示 五 炭

ス旦手

フ 1 術

モ

亦
第

總

括

及

ビ

考

按
示減一示於 就 ス 定 ステ キ 示ノモモテ 値六五 手于十! 前 術呈日!十篇 後主白 五一七心記 二干立五穛 十日旦名ル 日前二减 7 二後八少以 於寻略 シ テ

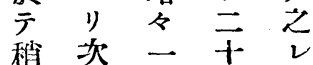
々 第定 日 减二七煩省 少總 ル寻略 示游見次 ス酸 ル 第 總 モノ。三脂 , 如 $ב$ 正 肪 アキレ 常 酸 ル遇ス値八 モ程 デ 各 次 $\ni$ 復 例 第取 ン シ チ 二リ八更通 增 テ一二 星增 例瀷五 シ 量量 I 五 日告 1 千於六二 七千示於 五 モ 跱 女秎 日亦减十各 八略少五减 格々 尹 日少 而亦二光 二 不傾 定者モ最向 シ 類他 モ 最符暫ク 高七時增市 値儿略量均 


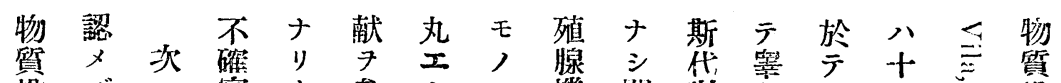

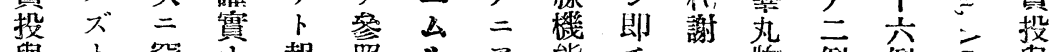

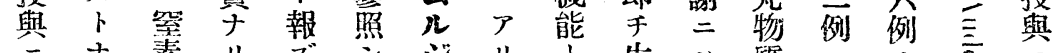
二ナ 素り ズ シ ジリト生入留三人

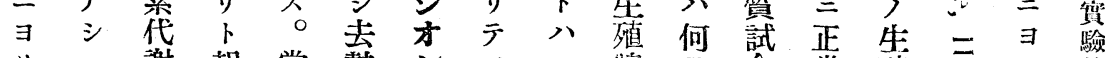

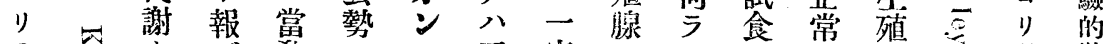

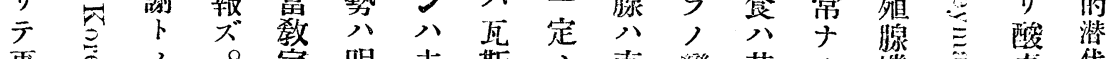

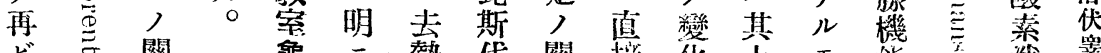

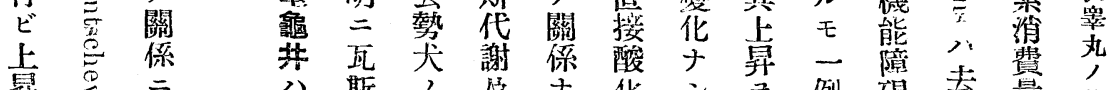

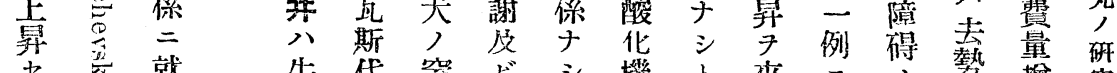

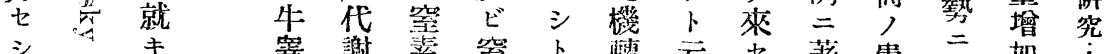

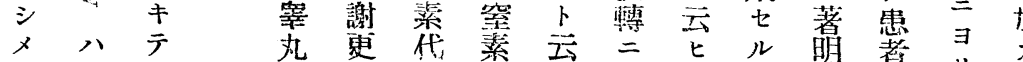

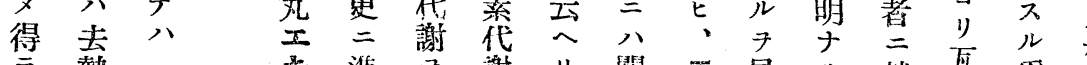

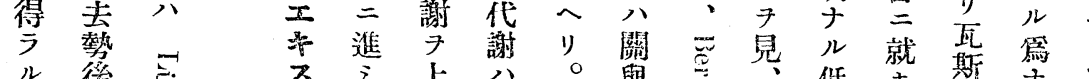

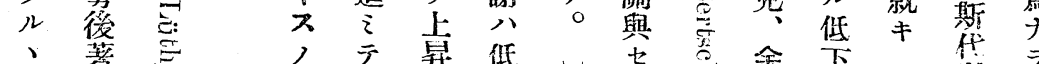

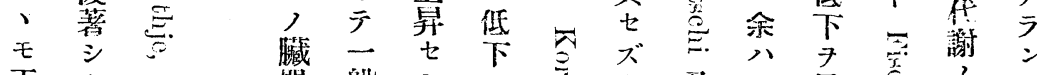

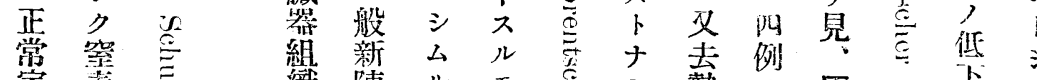

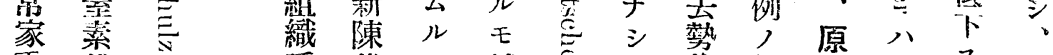

鬼帒 , 誰

窒突至 素减窟

代 退 謝

$\therefore$ 八

何認主

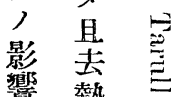

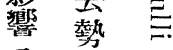

$\exists=$

認寻絫

ザ 市

り退素

キ 七 帒

薄 空

素何

代

离謝了關

要係

F杂 7

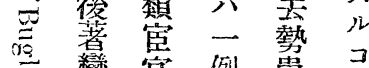

二ョ斯ザム紗宫例急コ他

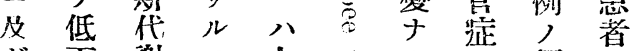

ボ市謝モ人たク類皇

ス七

影シ八二ビ主热官官就一

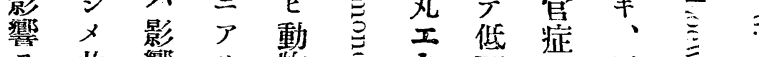

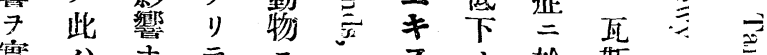

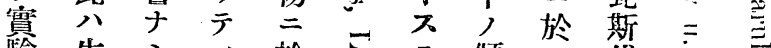

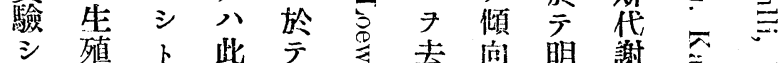

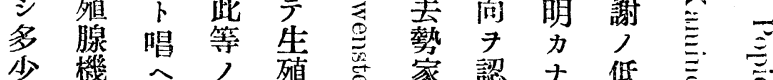

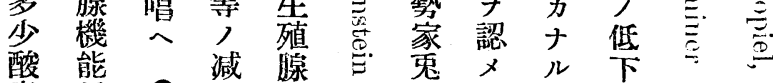

䇣低气少剔

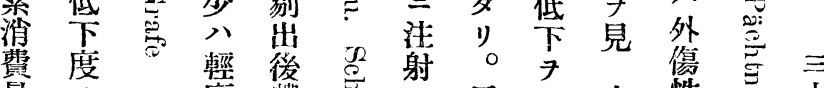

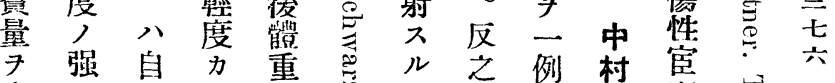

高毛或重空毛之例村官

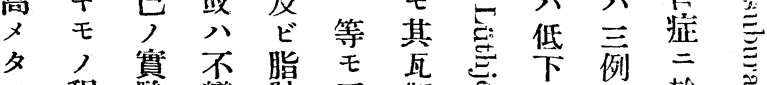

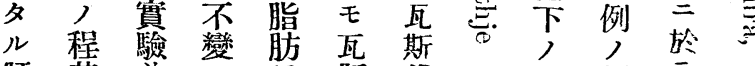

傾其亚三增斯代八傾類 $\bar{~}$

向 影 二 シ 加代謝去向宦 こ

ア響 多テ

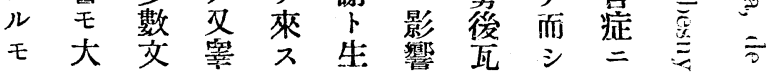




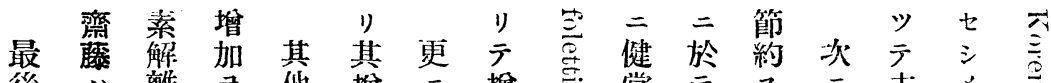

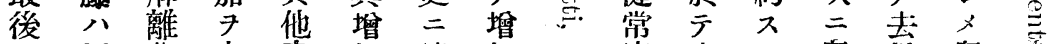

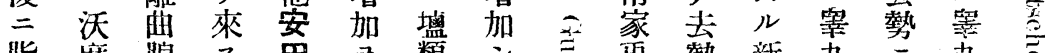

脂度腺

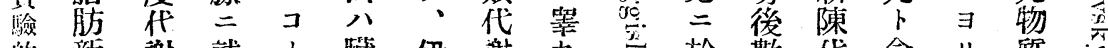

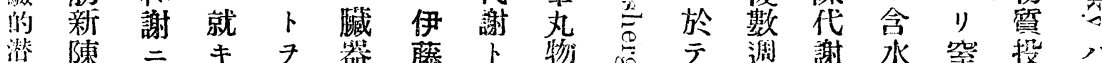

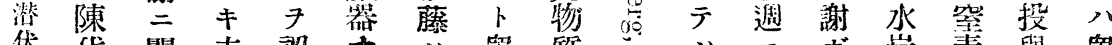

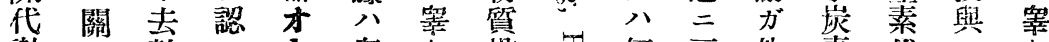

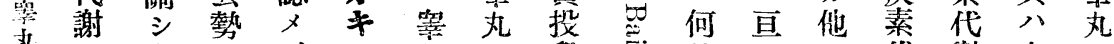

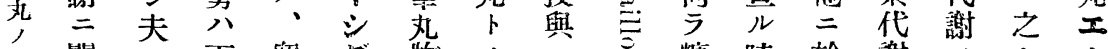

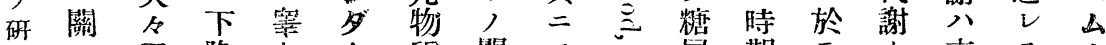

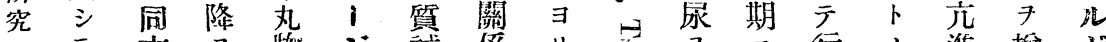

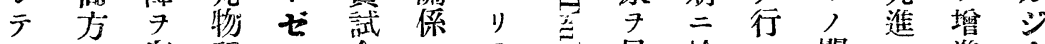

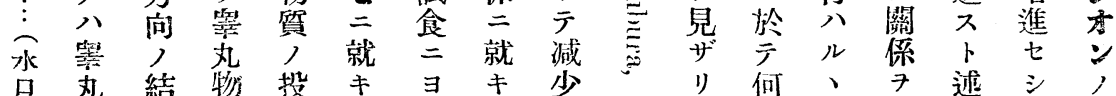

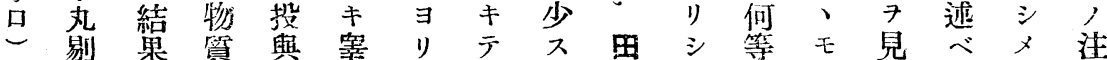

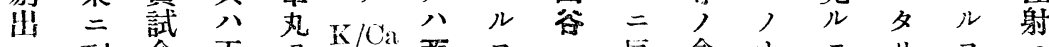

二到食正子 $\mathrm{K} / \mathrm{Ca}$ 酉コ仅食ナニリコさ

關洋八常剔商村卜伊 シ 慨ラ

シ 七其動

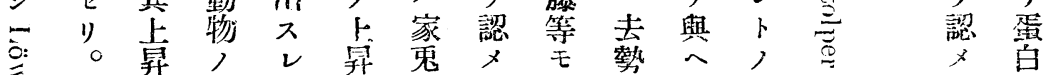

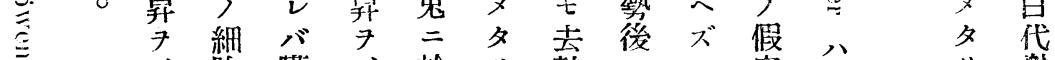

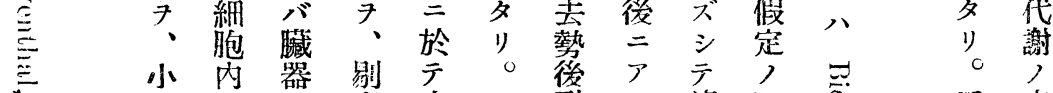

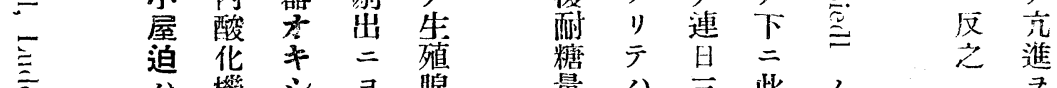

豆機

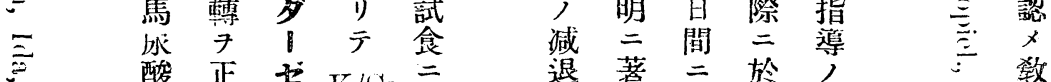

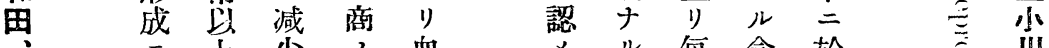

二上少, 血 $邓$ 每含於豆川

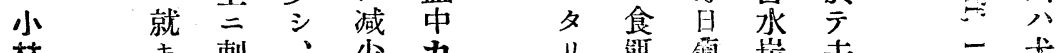

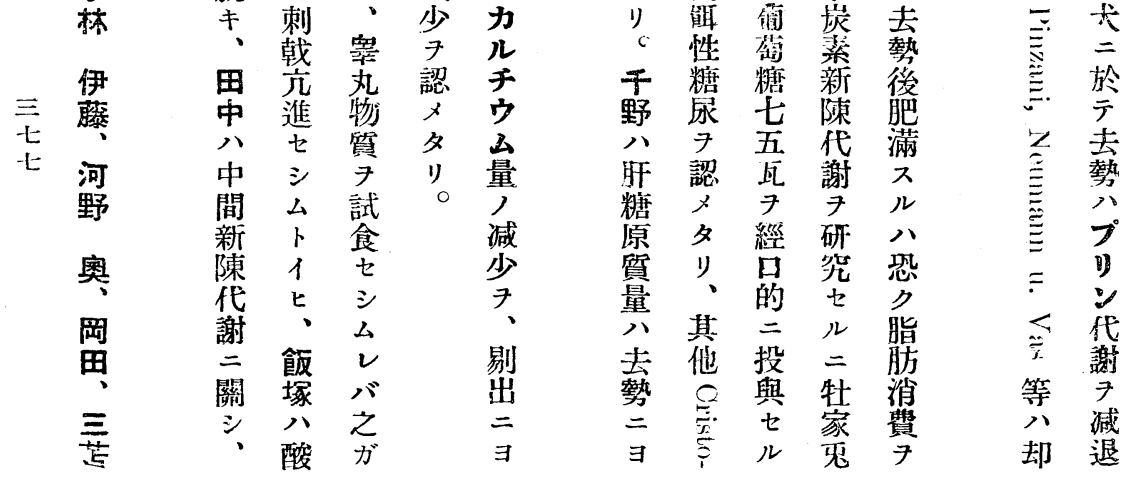


减ナ般 ケ謝二長二セレ有二十認等

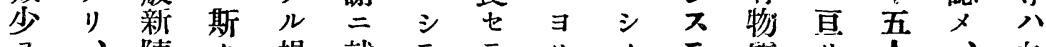

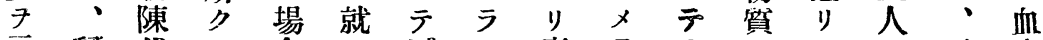

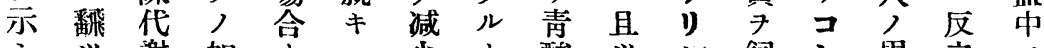

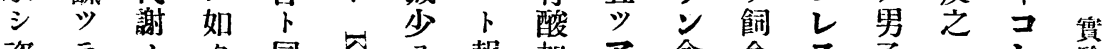

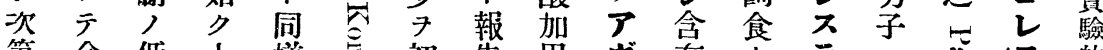

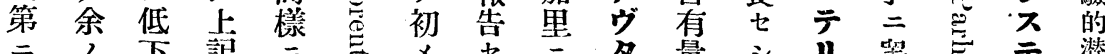

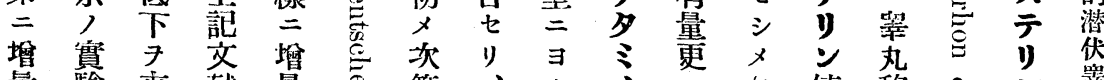

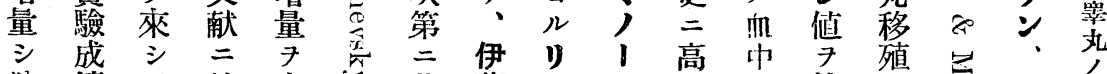

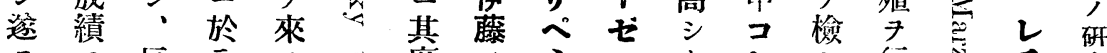

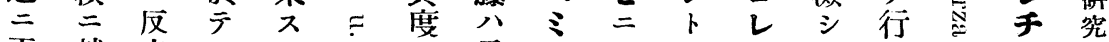

正就之

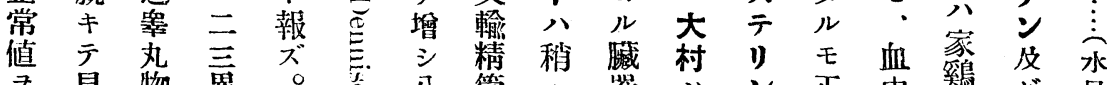

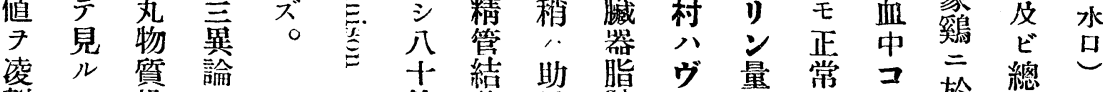

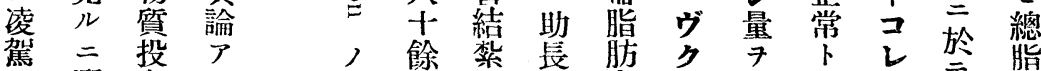

シ 潛興ル 白

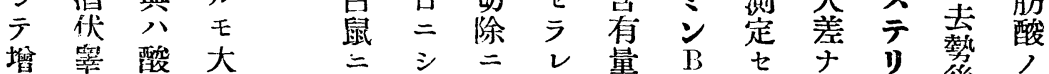

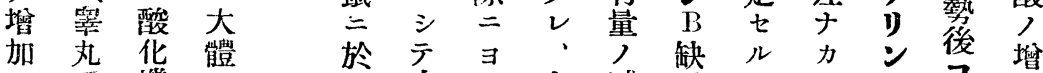

ス手機二 方次り少减芝二リ, コ加

而街能於 ル 第一量少食何キ、减 ス

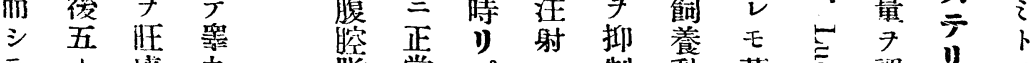

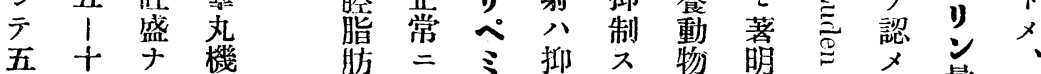

十1 ラ能量復 1 制卜云二及量河

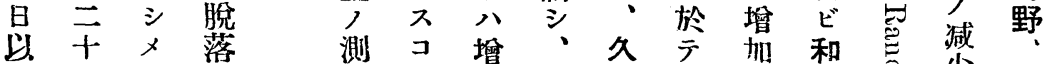

後日、齐 引 定

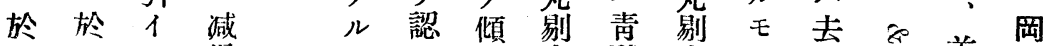

テ テ テ 退方

最中 一 ル

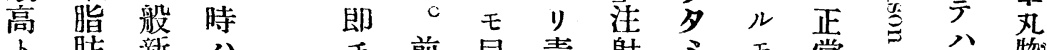

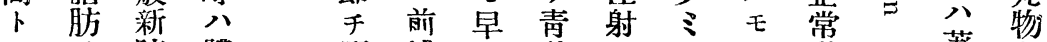

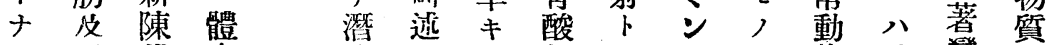

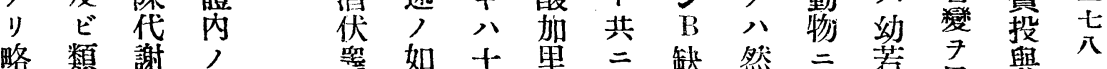

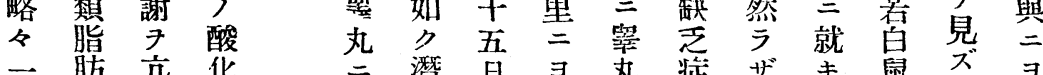

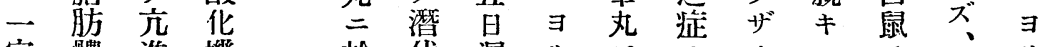

定體進機於伏僬ルエノルコゴ ル

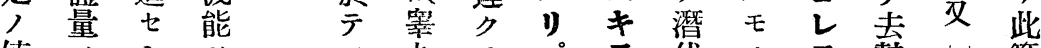

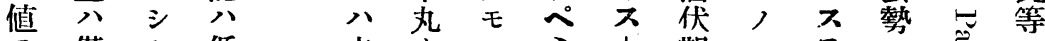

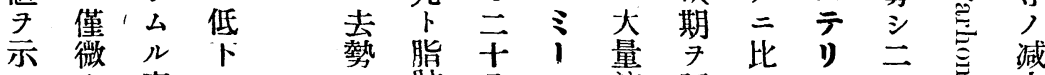

スナ事 シ 肪八六注延沙

二ル明- 於代日助射長コ含月少 


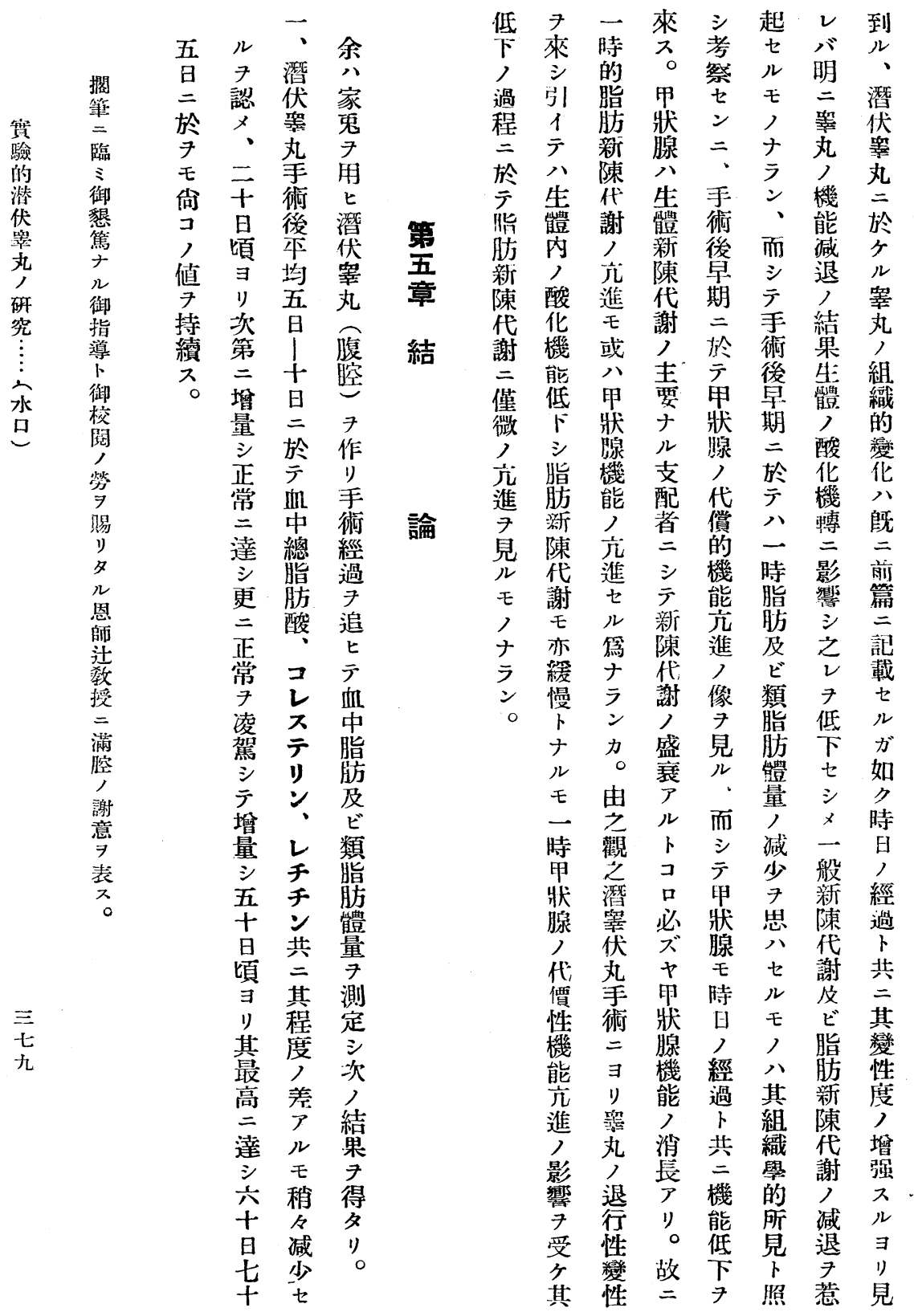




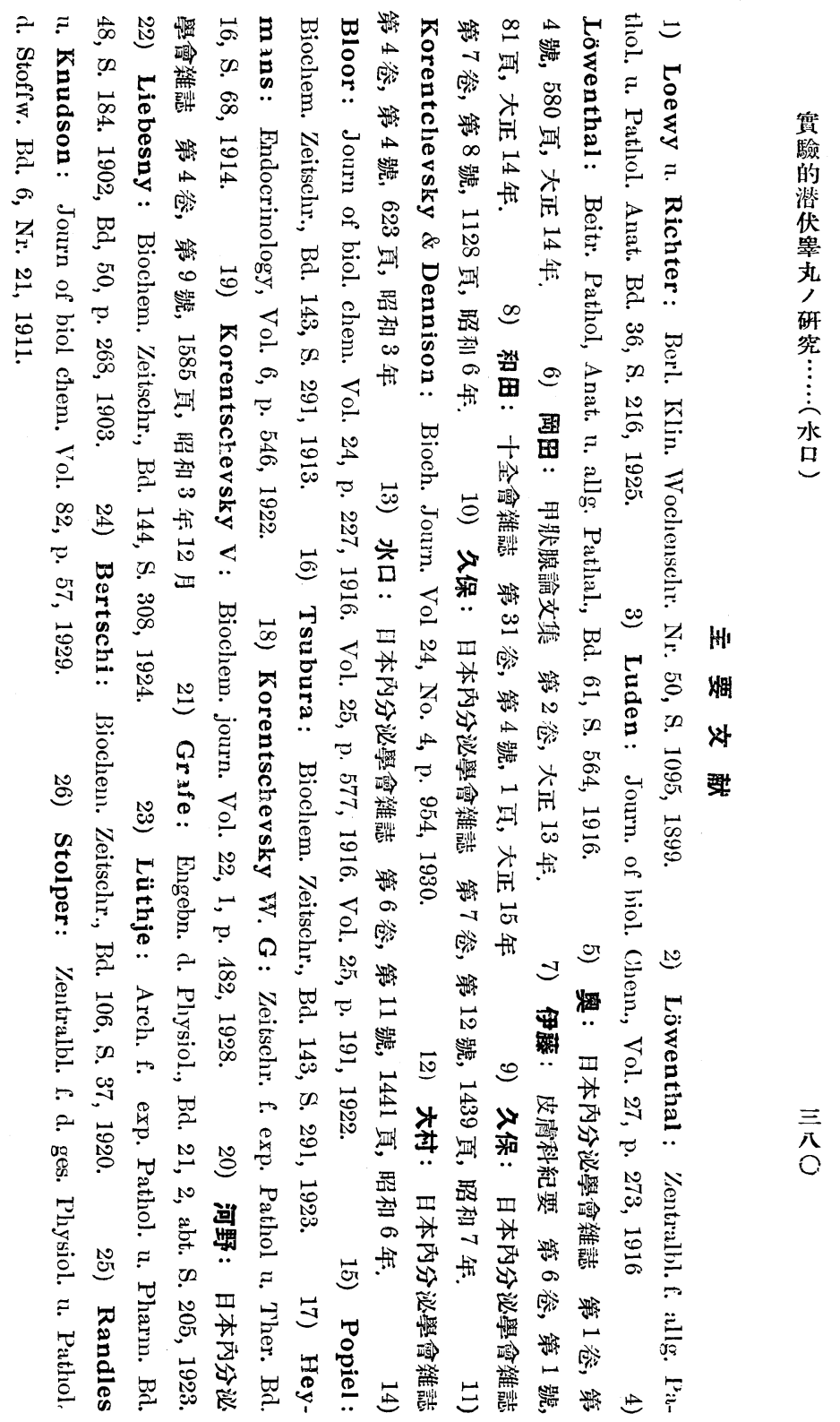


tologisch untersucht. Die Resultate waren die folgenden:

1) Die Schilddrüse bei der I. Gruppe zeigt das Bild der Hyperfunktion, d. h. kleinere Follikel mit dünner Kolloidmasse, hypertrophiertes, kubisches Follikelepithel mit rundlichem Kern und Gefässvermehrung. Bei der III. Gruppe findet sich das Bild der Hypofunktion, d. h. grössere Follikel mit dicker Kolloidmasse und atrophiertes, abgeplattetes Follikelepithel mit plattem Kern. Bei der II. Gruppe trägt das Bild Züge der I. und III. Gruppe, ähnelt aber etwas mehr dem der III. Gruppe als dem der T.

2) Die Hypophyse zeigt bei der I. Gruppe keine Veränderung. Bei der II. und III. Gruppe findet sich Vermehrung der eosinophilen Zellen, was bei der III. Gruppe stärker als bei der II. ausgesprochen ist.

3) Besonders deutlich ist die Veränderung der Hoden.' Bei allen 3 Gruppen sieht man Abnahme des Hodengewichtes von 1/5 bis zu 1/3, Verdickung der Tunica albuginea, Atrophie der Hodenkanälchen, Erloschensein der Spermien, Degeneration der Spermiden, Spermiocyten und Spermiogonien, wobei die Spermien am meisten gelitten haben und am wenigsten die Spermiogonien. Atrophie und Degeneration sind am auffallendsten bei der III. Gruppe.

4) Die anderen innersekretorischen Organe sind nicht nennenswert verändert.

(Autoreferat)

\title{
Studien über den experimentellen Kryptorchismus.
}

\section{Fett-und Lipoidgehalt des Blutes beim experimentellen Kryptorchismus.}

Von

\author{
Dr. H. Minakuchi.
}

(Aus der I. med. Klinik der Kaiserl. Universität zu Kyoto in Japan. Direktor : Prof. Dr. K. Tsuji.) 
Es ist allgemein bekannt, dass es bei dem Ausfall der Keimdrüsenhormone, z. B. im Klimakterium, bei Eunuchen, Eunuchoiden und Skopzen allmählich zu starker Fettablagerung kommt.

Der Verfasser untersuchte den Fett-und Lipoidgehalt des Blutes beim experimentellen Kryptorchismus. Das Experiment wurde an Kaninchen ausgeführt, und die Gesamtfettsäure, Cholesterin und Lecithin nach der Bloorschen Methode bestimmt. Die Resultate waren die folgenden :

Kurz nach der Operation nahmen Gesamtfettsäure, Cholesterin und Lecithin im Blute mehr oder weniger ab, aber schon nach 20 Tagen zeigten sie übernormale Werte. Am 50 Tage erreichte der Fettgehalt seinen Maximalwert und hielt als solcher bis zum 60-75. Tage post operat. an.

(Autoreferat)

\section{Ueber den Einfluss der verschiedenen inner- sekretorischen Drüsen auf die Indicanbildung im Organismus.}

\section{Mitteilung. Ueber den Einfluss der Schilddrüse.}

Von

Dr. Shiu Shingu.

(Aus der I. med. Klinik der Kaiserl. Universität zu Kyoto in Tapan. Direktor: Prof. Dr K. Tsuji.)

Um den Einfluss der Schilddrüse auf die Oxydation und Synthese im Organismus als Entgiftungsvorgang kennenzulernen und um zugleich zur Klarstellung des Mechanismus der Indicanbildung im Körper beizutragen, hat der Verfasser das vorliegende Experiment angestellt. Das Kaninchen wurde im Stoffwechselkäfig gehalten, mit einer bestimmten Menge Bohnenquark gefüttert und jeden Tag der 24-stündige Harn gesammelt. Im Harn wurde das Indican 